\title{
PENGARUH TEKNIK STORYTELLING DALAM LAYANAN BIMBINGAN KELOMPOK TERHADAP PENINGKATAN EMOTIONAL LITERACY SISWA \\ (Studi Eskperimen terhadap Siswa Kelas III SDN Jatinegara Kaum 14 Pagi)
}

\author{
Nira Prihatin Nufus ${ }^{1}$ \\ Retty Filiani ${ }^{2}$ \\ Moch. Dimyati ${ }^{3}$
}

\begin{abstract}
Abstrak
Penelitian ini bertujuan untuk mengetahui pengaruh teknik storytelling dalam layanan bimbingan kelompok terhadap peningkatan emotional literacy siswa. Penelitian ini dilaksanakan pada siswa kelas III SDN Jatinegara Kaum 14 Pagi pada bulan Februari-Desember 2015. Metode penelitian yang digunakan dalam penelitian ini adalah Pre-Eksperimental Design dengan bentuk one group pretestposttest. Instrumen emotional literacy memiliki 45 item butir pernyataan yang valid dan memiliki koefisien reliabilitas sebesar 0,893 . Hal tersebut menyimpulkan bahwa instrumen tersebut layak dan dapat dipergunakan dalam penelitian ini. Teknik analisis data yang digunakan dalam menguji hipotesis pada penelitian ini adalah Wilcoxon Match Pairs Test untuk membandingkan hasil pretest dan posttest. Berdasarkan hasil pengujian hipotesis diperoleh hasil asymp. Sig sebesar 0,012 yang berarti lebih kecil dari signifikansi $\alpha=0.05$. Hal ini menunjukkan bahwa $\mathrm{H}_{0}$ ditolak dan $\mathrm{H}_{1}$ diterima, yaitu terjadi peningkatan emotional literacy siswa kelas III SDN Jatinegara Kaum 14 Pagi secara signifikan setelah diberikan teknik storytelling dalam layanan bimbingan kelompok.
\end{abstract}

Kata Kunci: Storytelling, Emotional Literacy

\section{PENDAHULUAN}

Seorang anak akan tumbuh dan berkembang menjadi pribadi dewasa yang sehat ketika ia mampu melewati tugas-tugas perkembangannya dengan baik. Anak usia enam sampai dua belas tahun adalah masa anak untuk masuk ke lingkungan sekolah, yang mempunyai kondisi dan situasi berbeda sekali dengan keluarganya.

Pembelajaran di dalam kelas lebih banyak mengembangkan aspek intelektual anak, sementara di luar kelas saat anak bergaul dengan teman sebayanya juga memerlukan perkembangan aspek emosi dimana pada usia tersebut kondisi kehidupan emosional anak belum begitu berkembang.

Pola emosi pada anak hampir sama dengan orang dewasa, namun berbeda dari sisi rangsangan yang membangkitkannya serta cara mengekspresikannya. Rangsangan yang sering membangkitkan emosi anak adalah keinginan yang tidak terpenuhi, dengan cara mengungkapkan ekspresi yang tidak terkendali.

Ekspresi emosi yang baik pada anak dapat menimbulkan penilaian sosial yang menyenangkan. Sebaliknya ekspresi emosi yang kurang baik seperti cemburu, marah, atau takut dapat menimbulkan penilaian sosial yang tidak menyenangkan. Oleh

\footnotetext{
${ }^{1}$ Mahasiswa Program Studi Bimbingan dan Konseling FIP UNJ, nirapn08@gmail.com

${ }^{2}$ Dosen Program Studi Bimbingan dan Konseling FIP UNJ, rettyfiliani@yahoo.co.id

${ }^{3}$ Dosen Program Studi Bimbingan dan Konseling FIP UNJ, mochamad.dimyati@gmail.com
} 
karena itu, dibutuhkan kemampuan yang perlu dikembangkan dan dimiliki oleh anak berkaitan dengan emosi.

Salah satu kemampuan yang dapat dikembangkan oleh anak berkaitan dengan emosi adalah emotional literacy. Emotional literacy dapat didefinisikan sebagai kemampuan untuk mengenali, memahami, menangani, dan tepat mengekspresikan emosi.

Penelitian telah menunjukkan bahwa individu dengan skor emotional literacy yang lebih tinggi memiliki kualitas persahabatan yang lebih baik. Selain itu, orang-orang dengan skor emotional literacy yang lebih tinggi tampaknya mampu menangani stres secara lebih baik, dan menunjukkan berkurangnya masalah perilaku dan lebih berperilaku prososial (Brackett, Rivers, \& Salovey, 2005).

Bercerita menjadi bagian yang penting dalam aspek perkembangan anak, saat membaca atau mendengarkan cerita anak akan belajar mengembangkan bahasa, emosi, sosialisasi, kognitif, partisipatif, kebiasaan bekerja dan pengembangan fisik motoriknya. Tujuannya adalah untuk membantu anak-anak mendalami perasaan dan mengkomunikasikan pengalamanpengalaman, nilai, dan standar perilaku mereka (Thompson, 2004).

Berdasarkan permasalahan yang terjadi di atas, maka rumusan masalah dalam penelitian ini adalah mengenai: "Apakah terdapat Pengaruh Teknik Storytelling dalam Layanan Bimbingan Kelompok terhadap Peningkatan Emotional literacy Siswa Kelas III SDN Jatinegara Kaum 14 Pagi?"

\section{KAJIAN TEORETIK STORYTELLING}

Menurut Echols "storytelling terdiri atas dua kata yaitu story yang berarti cerita, dan telling berarti penceritaan." Penggabungan dua kata tersebut (storytelling) berarti penceritaan cerita atau menceritakan cerita. Menurut Joseph Frank yang dikutip oleh Asfandiyar, storytelling merupakan salah satu cara yang efektif untuk mengembangkan aspek-aspek kognitif (pengetahuan), afektif (perasaan), sosial, dan aspek konatif (penghayatan) anak-anak (Asfandiyar, 2007). Menurut Abdul Aziz Abdul Majid paling tidak ada 3 komponen dalam bercerita, yaitu: (1) storyteller (pencerita); (2) cerita atau karangan yang disampaikan, (3) penyimak (Majid, 2013). Tujuan storytelling adalah mengembangkan beberapa aspek yaitu aspek perkembangan bahasa, aspek perkembangan sosial, aspek perkembangan emosi, aspek perkembangan kognitif, dan aspek perkembangan moral (Musfiroh, 2005).

Manfaat storytelling yaitu untuk membantu pembentukan pribadi, moral, dan sosial, menyalurkan kebutuhan imajinasi dan fantasi, memacu kemampuan verbal, dan merangsang kecerdasan emosi (Musfiroh, 2005).

Menurut Moeslikhatoen R (Farida, 2008), beberapa macam teknik storytelling, antara lain yaitu storytelling dengan membaca buku cerita, ilustrasi gambar, papan flannel, media boneka, dramatisasi, dan memainkan jari tangan. Ada tiga tahapan dalam storytelling, yaitu persiapan sebelum storytelling, saat proses storytelling berlangsung, dan kegiatan storytelling selesai (Bunanta, 2009).

\section{BIMBINGAN KELOMPOK}

Bimbingan kelompok merupakan suatu proses pemberian bantuan kepada individu melalui suasana kelompok yang memungkinkan setiap anggota untuk belajar berpartisipasi aktif dan berbagi pengalaman dalam upaya pengembangan wawasan, sikap dan atau keterampilan yang diperlukan dalam upaya mencegah timbulnya masalah atau dalam upaya pengembangan pribadi (Rusmana, 2009).

Pada umumnya ada empat tahap perkembangan, yaitu tahap pembentukan, tahap peralihan, tehap pelaksanaan kegiatan, dan tahap pengakhiran (Prayitno, 1995). Tahap-tahap ini merupakan suatu kesatuan dalam seluruh kegiatan kelompok. 


\section{EMOTIONAL LITERACY}

Brackett dan Rivers dalam Hughes mengemukakakan emotional literacy merupakan suatu kemampuan yang berfungsi untuk mengenali, memahami, menamai, mengungkapkan dan mengatur emosi, baik emosi secara personal, sosial dan intelektual (Hughes, dkk, 2009). Emotional literacy dapat berkontribusi pada kesehatan, hubungan positif, sukses, dan kualitas hidup.

Menurut Bracket \& Rivers (Hughes, dkk, 2009) emotional literacy terdiri dari lima aspek, yaitu recognize, understand, label, express, dan regulate atau biasa disingkat RULER.

1. Recognize

Kemampuan pada individu untuk mengidentifikasi dan menafsirkan pengalaman emosi berdasarkan isyarat nonverbal, termasuk ekspresi wajah, gaya berjalan, postur tubuh, suara, gestur, sentuhan, dan perubahan fisiologis.

2. Understand

Kemampuan pada individu untuk menyadari sebab dan akibat emosi, termasuk situasi penyebab emosi, transisi dan perkembangan antar emosi, dan bagaimana emosi memengaruhi pikiran dan perilaku.

3. Label

Kemampuan individu untuk mampu mengembangkan berbagai istilah kosakata untuk menggambarkan berbagai macam emosi.

4. Express

Kemampuan individu untuk mengetahui beberapa bentuk dari ekspresi emosi, termasuk cara berbicara, menulis, dan nonverbal, serta menyadari bentuk dan waktu yang tepat ketika mengekspresikan emosi, tergantung kepada konteksnya dan lawan bicara.

5. Regulate

Kemampuan yang dimiliki seorang individu untuk menentukan strategi untuk mengubah keadaan emosi: seperti mencegah, meningkatkan, mengurangi, dan memicu diri sendiri dan orang lain sesuai situasi.

\section{METODOLOGI PENELITIAN}

Penelitian ini bertujuan untuk mengetahui pengaruh teknik storytelling dalam layanan bimbingan kelompok terhadap peningkatan emotional literacy siswa kelas III SDN Jatinegara Kaum 14 Pagi. Penelitian ini dilakukan pada bulan Februari hingga Desember 2015 di SDN Jatinegara Kaum 14 Pagi yang beralamat di Jalan Jatinegara Kaum Rt.10/Rw.03, Jakarta Timur. Metode penelitian yang akan digunakan dalam penelitian ini adalah metode eksperimen. Metode eksperimen adalah metode yang digunakan untuk mencari pengaruh perlakuan tertentu terhadap yang lain dalam kondisi yang terkendalikan (Sugiyono, 2010). Jenis penelitian eksperimen yang digunakan adalah Pre-Experimental Design dengan bentuk the one group pretest-posttest. Penelitian the one group pretest-posttest melibatkan kelompok tunggal, tanpa memasukkan kelompok kontrol sebagai kelompok pembanding (Emzir, 2009). Populasi penelitian ini adalah seluruh siswa kelas III SDN Jatinegara Kaum 14 Pagi sebanyak 32 orang.

Teknik pengambilan sampel yang digunakan untuk memilih subjek penelitian adalah teknik Purposive Sampling atau sampel bertujuan. Skala pengukuran yang digunakan dalam penelitian ini adalah model skala Likert. Model skala Likert digunakan untuk mengukur sikap, pendapat, persepsi seseorang atau sekelompok orang tentang suaru gejala atau fenomena (Wahyuni \& Rangkuti, 2012).

Peneliti melakukan uji validitas konstruk (construct validity) dengan menggunakan pendapat ahli (judgment experts). Selain itu, pengujian validitas akan dilakukan dengan menggunakan teknik Product Moment Pearson dengan bantuan aplikasi Statistical Package for Social Science versi 20.0.

Setelah dilakukan uji validitas, dari 60 butir pernyataan yang diujikan, 45 butir pernyataan dinyatakan valid dan 15 lainnya 
dinyatakan tidak valid.

Dalam penelitian ini data akan dikategorikan dengan tiga kriteria yaitu rendah, sedang, dan tinggi dengan menyusun kelas interval dari data dengan menggunakan rumus sebagai berikut (Supranto, 2001):

$$
c=(X n-X 1) / k
$$

Keterangan:

$c \quad$ : Panjang kelas

$X n \quad$ : Nilai terbesar

$X 1 \quad$ : Nilai terkecil

$\mathrm{k} \quad$ : Banyaknya kelas

Teknik analisis data dalam penelitian ini menggunakan Wilcoxon Match Pairs Test dengan menggunakan bantuan aplikasi SPSS versi 20.0. Wilcoxon Match Pairs Test digunakan untuk menguji hipotesis komparatif dua sampel berkorelasi bila datanya berbentuk ordinal (Sugiyono, 2008).

\section{HASIL DAN PEMBAHASAN}

Berdasarkan data dari instrumen emotional literacy yang diberikan diperoleh hasil data sebagai berikut :

Tabel 1

Data pretest dan posttest emotional literacy

\begin{tabular}{cccc}
\hline \multirow{2}{*}{ Kategori } & Rentang Skor & \multicolumn{2}{c}{ Frekuensi } \\
& & Pretest & Posttest \\
\hline Rendah & $68-81$ & 8 & 0 \\
Sedang & $82-96$ & 0 & 6 \\
Tinggi & $97-110$ & 0 & 2 \\
& Jumlah & 8 & 8 \\
\hline
\end{tabular}

Berdasarkan data hasil pretest instrumen emotional literacy diketahui bahwa capaian skor kedelapan siswa berada pada kategori rendah. Setelah diberikan teknik storytelling dalam layanan bimbingan kelompok, siswa diberikan posttest menggunakan instrumen emotional literacy untuk mengetahui peningkatan atau penurunan ketegorisasi. Dari data hasil posttest, siswa mengalami peningkatan emotional literacy. Hasil capaian skor seluruh siswa menunjukkan bahwa kondisi siswa meningkat menjadi kategori sedang dan tinggi.

Capaian skor emotional literacy anggota kelompok sebagai berikut:

Tabel 2

Data skor pretest dan posttest emotional literacy per individu

\begin{tabular}{ccccccc}
\hline \multirow{2}{*}{ Nama } & \multicolumn{2}{c}{ Pretest } & \multicolumn{2}{c}{ Posttest } \\
& Skor & $\%$ & Skor & $\%$ & Peningkatan \\
& \multicolumn{5}{c}{ Skor Ideal : 120} \\
AAI & 76 & 63,3 & 87 & 72,5 & 11 & 9,2 \\
ANK & 79 & 65,8 & 91 & 75,8 & 12 & 10 \\
AMS & 72 & 60 & 86 & 71,7 & 14 & 11,7 \\
HMP & 76 & 63,3 & 99 & 82,5 & 23 & 19,2 \\
RHNP & 68 & 56,7 & 85 & 70,8 & 17 & 14,2 \\
RRH & 78 & 65 & 89 & 74,2 & 11 & 9,2 \\
RA & 77 & 64,2 & 97 & 80,8 & 20 & 16,7 \\
ZR & 80 & 66,7 & 89 & 74,2 & 9 & 7,5 \\
\hline
\end{tabular}

Berdasarkan data pada tabel, terlihat peningkatan skor pretest dan posttest setiap individu dalam kelompok yang telah mendapatkan perlakuan berupa teknik storytelling dalam layanan bimbingan kelompok untuk meningkatkan emotional literacy siswa.

Dari hasil pretest, kedelapan siswa yang akan mendapatkan perlakuan teknik storytelling dalam layanan bimbingan kelompok berada pada kategori rendah. Setelah mendapatkan perlakuan teknik storytelling dalam layanan bimbingan kelompok hasil posttest kedelapan siswa meningkat menjadi kategori sedang dan tinggi. Dengan rincian enam orang pada kategori sedang yaitu AAI, ANK, AMS, RHNP, RRH, ZR, dan dua orang pada kategori tinggi yaitu HMP dan RA.

Tabel 3

Rata-Rata Skor Pretest dan Posttest Emotional

\begin{tabular}{cccccc}
\multicolumn{5}{c}{ Literacy } \\
\hline Pretest & $\%$ & Posttest & $\%$ & \multicolumn{2}{c}{ Peningkatan } \\
\hline 75,75 & 63,1 & 90,38 & 75,3 & 14,62 & 12,18 \\
\hline
\end{tabular}

Berdasarkan tabel di atas, didapatkan hasil rata-rata skor pretest sebesar 75,75 dan rata-rata skor posttest sebesar 90,38. Terdapat 
peningkatan antara hasil pretest dan posttest setelah diberikan perlakuan sebesar 14,62 dengan persentase $12,18 \%$.

\section{Tabel 4}

Data skor pretest dan posttest emotional literacy setiap aspek

\begin{tabular}{ccccccc}
\hline \multirow{2}{*}{ Aspek } & $\begin{array}{c}\text { Skor } \\
\text { Ideal }\end{array}$ & \multicolumn{2}{c}{ Skor Pretest } & \multicolumn{2}{c}{ Skor Posttest } \\
\hline Recognize & 256 & 168 & $65,6 \%$ & 196 & $76,6 \%$ \\
Understand & 192 & 115 & $59,9 \%$ & 139 & $72,4 \%$ \\
Label & 64 & 35 & $54,7 \%$ & 47 & $73,4 \%$ \\
Express & 192 & 129 & $67,2 \%$ & 152 & $79,2 \%$ \\
Regulate & 256 & 159 & $62,1 \%$ & 189 & $73,3 \%$ \\
\hline
\end{tabular}

Berdasarkan hasil perhitungan menggunakan Wilcoxon Match Pairs Test dengan SPSS 20.0, diperoleh nilai asymp. Sig $=0.012<$ nilai signifikan $\alpha=0.05$, yang berarti $\mathrm{H}_{0}$ ditolak. Dengan demikian dapat diartikan bahwa teknik storytelling dalam layanan bimbingan kelompok berpengaruh positif untuk meningkatkan emotional literacy siswa kelas III SD Negeri Jatinegara Kaum 14 Pagi.

Hasil penelitian berdasarkan uji hipotesis menunjukkan bahwa $\mathrm{H}_{0}$ ditolak, hal ini dapat diartikan teknik storytelling dalam layanan bimbingan kelompok berpengaruh positif untuk meningkatkan emotional literacy siswa kelas III SD Jatinegara Kaum 14 Pagi yang menjadi responden dalam penelitian. Jumlah siswa yang memiliki emotional literacy yang rendah pada pretest yaitu sebanyak delapan orang. Dari frekuensi tersebut sebanyak enam orang meningkat menjadi kategori sedang, dan dua orang menjadi kategori tinggi.

Berdasarkan analisis data, diketahui bahwa terdapat peningkatan emotional literacy siswa pada setiap aspek emotional literacy. Peningkatan emotional literacy tersebut dilihat berdasarkan instrumen emotional literacy yang diberikan pada siswa sebelum dan sesudah diberikan teknik storytelling dalam layanan bimbingan kelompok.

Kegiatan storytelling di sekolah dasar umumnya berada dalam setting kelompok yang dapat berupa kelompok kecil dengan anggota sekitar lima sampai sepuluh orang atau dapat juga berupa kelompok besar yaitu lebih dari sepuluh orang. Hal tersebut juga selaras dengan layanan bimbingan kelompok di sekolah dasar dimana salah satunya siswa butuh untuk bekerja dalam suatu kelompok, bergaul dengan teman sebaya, mempelajari berbagai aspek penting dalam proses sosialisasi, seperti belajar memenuhi aturanaturan kelompok, belajar setia kawan, belajar menerima tanggung jawab, dan belajar bersaing dengan orang lain secara sehat (sportif).

Bimbingan kelompok merupakan suatu proses pemberian bantuan kepada individu melalui suasana kelompok yang memungkinkan setiap anggota untuk belajar berpartisipasi aktif dan berbagi pengalaman dalam upaya pengembangan wawasan, sikap dan atau keterampilan yang diperlukan dalam upaya mencegah timbulnya masalah atau dalam upaya pengembangan pribadi (Rusmana, 2009). Melalui teknik storytelling dalam layanan bimbingan kelompok, siswa diajak untuk mengenal emosi lebih dalam diantaranya yaitu mengidentifikasi emosi dari ekspresi wajah dan suara, mengidentifikasi sebab dan akibat emosi dalam cerita, menamai emosi-emosi dalam cerita, mempelajari mengekspresikan emosi yang tepat, dan mempelajari bagaimana seharusnya bersikap. Kegiatan tersebut mengembangkan sisi emotional literacy siswa, dimana emotional literacy merupakan sebuah kemampuan mendasar untuk mengenali, memahami, menamai, mengungkapkan, dan mengatur emosi secara personal, sosial, dan intelektual.

Pada setiap sesi pertemuan layanan bimbingan kelompok dengan teknik storytelling, siswa diberikan kegiatankegiatan yang menunjang pengembangan emotional literacy. Hal tersebut dapat terlihat dari hasil posttest setelah diberikannya perlakuan teknik storytelling dalam layanan bimbingan kelompok yang menunjukkan terdapat peningkatan terhadap emotional literacy siswa.

Keterbatasan penelitian ini diantaranya yaitu: (1) Tidak tersedianya 
ruangan khusus yang kondusif untuk melaksanakan kegiatan bimbingan kelompok.

(2) Waktu yang terlalu singkat dan mendesak dengan waktu ujian saat pemberian perlakuan teknik storytelling dengan layanan bimbingan kelompok di sekolah penelitian. (3) Peneliti menggunakan sebagian data screening yang berjarak kurang dari satu minggu sebagai data pretest. (4) Peneliti hanya menggunakan beberapa indikator saja yang terdapat pada aspek recognize untuk menyusun kisi-kisi instrument. (5) Peneliti tidak menggunakan bantuan observer lain dalam mengamati anggota kelompok saat perlakuan diberikan.

\section{KESIMPULAN DAN SARAN}

Terdapat pengaruh positif dari kegiatan bimbingan kelompok dengan teknik storytelling terhadap emotional literacy siswa SDN Jatinegara Kaum 14 Pagi. Berdasarkan hasil uji hipotesis, diperoleh data bahwa: nilai asymp. Sig $=0.012<$ nilai signifikan $\alpha=0.05$, yang berarti $\mathrm{H}_{0}$ ditolak. Dengan demikian dapat diartikan bahwa layanan bimbingan kelompok dengan teknik storytelling berpengaruh positif untuk meningkatkan emotional literacy siswa kelas III SD Negeri Jatinegara Kaum 14 Pagi.

Terdapat peningkatan emotional literacy pada diri responden setelah mendapatkan perlakuan (treatment) bimbingan kelompok dengan teknik storytelling. Berdasarkan hasil penelitian, dari delapan responden yang termasuk kategori emotional literacy rendah kemudian diberikan perlakuan bimbingan kelompok dengan teknik storytelling mengalami peningkatan emotional literacy, dua orang menjadi kategori tinggi dan enam orang menjadi kategori sedang.

Berdasarkan hasil penelitian, saran-saran yang dapat dipertimbangkan yaitu: Guru / wali kelas dapat menggunakan teknik storytelling dalam menyampaikan materi pelajaran sehingga siswa tidak jenuh dengan metode pembelajaran yang ada. Teknik storytelling dapat di masukan ke dalam materi pembelajaran Bahasa Indonesia, Pendidikan Agama, dan Pendidikan Kewarganegaraan (Pkn). Bagi peneliti selanjutnya yang ingin mengembangkan penelitian serupa sebaiknya memperkaya sumber bacaan dan referensi baik mengenai teori storytelling dan teori emotional literacy; membuat rencana pelaksanaan layanan (RPL) dengan kreatif yang dapat menunjang peningkatan emotional literacy siswa; melibatkan observer lain untuk mengamati siswa pada saat perlakuan diberikan.

\section{DAFTAR PUSTAKA}

Asfandiyar, A.Y. (2007). Cara Pintar Mendongeng. Jakarta: Mizan.

Brackett, M. A., Rivers, S., \& Salovey, P. (2005). Emotional Intelligence and its relation to social, emotional and academic outcomes among adolescents. Unpublished Data: Yale University.

Bunanta, M. (2009). Buku, Dongeng, dan Minat Baca. Jakarta: Murti Bunanta Foundation

Emzir. (2009). Metodologi Penelitian Pendidikan: Kuantitatif \& Kualitatif. Jakarta: RajaGrafindo Persada.

Farida, E.. (2015) Teknik Bercerita dalam Bimbingan dan Konseling, 2008, (https://ellafaridatizen.wordpress. com/2008/05/22/teknik-berceritadalam-bimbingan-konseling-seri-4/). Diunduh tanggal 20 September 2015.

Hughes, M., Thomphson, H. L., \& Terrell, J. B. (2009). Handbook for Developing Emotional and Sosial Intelligence. San Fransisco: Pfeiffer.

Majid, A.A.A. (2013). Mendidik dengan Cerita. Bandung: Remaja Rosdakarya.

Musfiroh, T. (2005). Cerita dan Perkembangan Anak. Yogyakarta: Navila.

Prayitno. (1995). Layanan Bimbingan dan Konseling Kelompok. Jakarta: Balai Pustaka

Rusmana, N. (2009). Bimbingan dan 
Konseling Kelompok di Sekolah.

Bandung: Rizqi Press.

Sugiyono. (2010). Metode Penelitian

Pendidikan: Pendekatan Kuantitatif,

Kualitatif dan $R \& D$. Bandung:

Alfabeta.

Supranto. (2001). Statistik: Teori dan Aplikasi (6th ed.). Jakarta: Erlangga.

Thompson, C. L. (2004). Counseling Children and Adolescents (6th ed.). 6 Edition. Boston: Brooks Cole.

Wahyuni, L.D., \& Rangkuti, A.A. (2012).

Penyusunan Skala Psikologis. Jakarta: FIP Press. 